U.S. Department of the Interior U.S. Geological Survey

\section{The Colorado River in Grand Canyon: How Fast Does It Flow?}

Opening the jet tubes at Glen Canyon Dam on March 26, 1996, released from Lake Powell a controlled flood of water that traveled down the Colorado River in Grand Canyon. How fast did the water move? How long did it take for water to reach a particular point along the river? The answers to these questions are important because the speed of river water affects the amount of physical and chemical changes, such as warming by sunlight, that the water will undergo as it moves downstream. Also, very fine particles and substances dissolved in the water travel along with the water, and the speed of the water tells us how fast these move downstream.

\section{How is the Water Speed Measured?}

One way to measure the speed of water is to tag it with a harmless substance that is easily identified and measured with the proper instruments. These substances are called water tracers and are commonly used in both ground water and surface water to track the water movement. A fluorescent dye developed specifically for this purpose has been used in surface-water studies for many years because it is safe and readily detectable at very low concentrations.

To make a measurement, dye is put into the river as nearly as possible at a single point and time. Samples of river water are collected at sites of known distances downstream as the dyed water passes. The samples are measured using an instrument designed to detect the very small amounts of dye present. The speed of the center of mass of the dyed water is determined from the data and represents the average speed of the water through the reach for the discharge during the measurement.

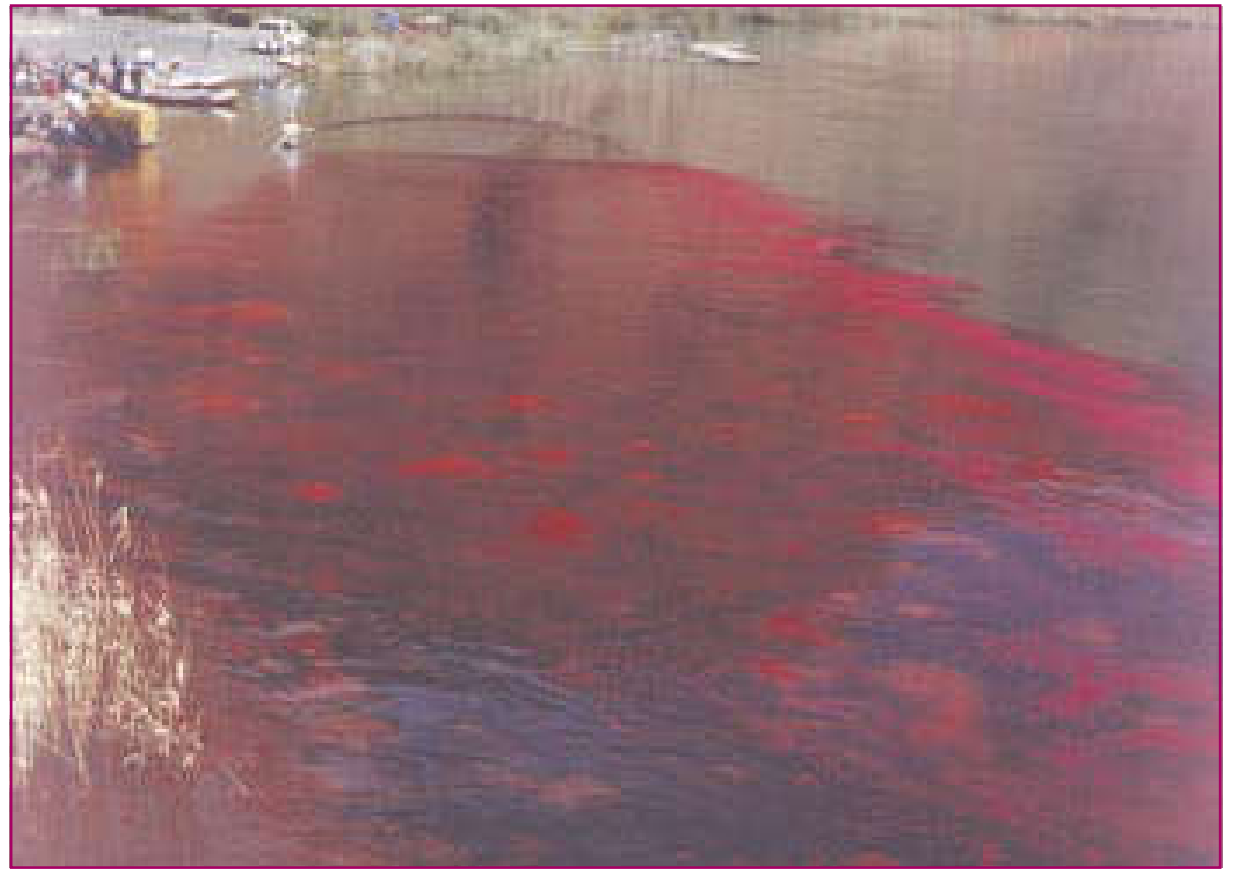

Athough the dye is easy to see where it is first put into the river, it quickly mixes with the much larger mass of river water and becomes invisible. The highest concentration at sampling sites was between 5 and 35 parts per billion. One part per billion is about equal to one drop in a backyard swimming pool.

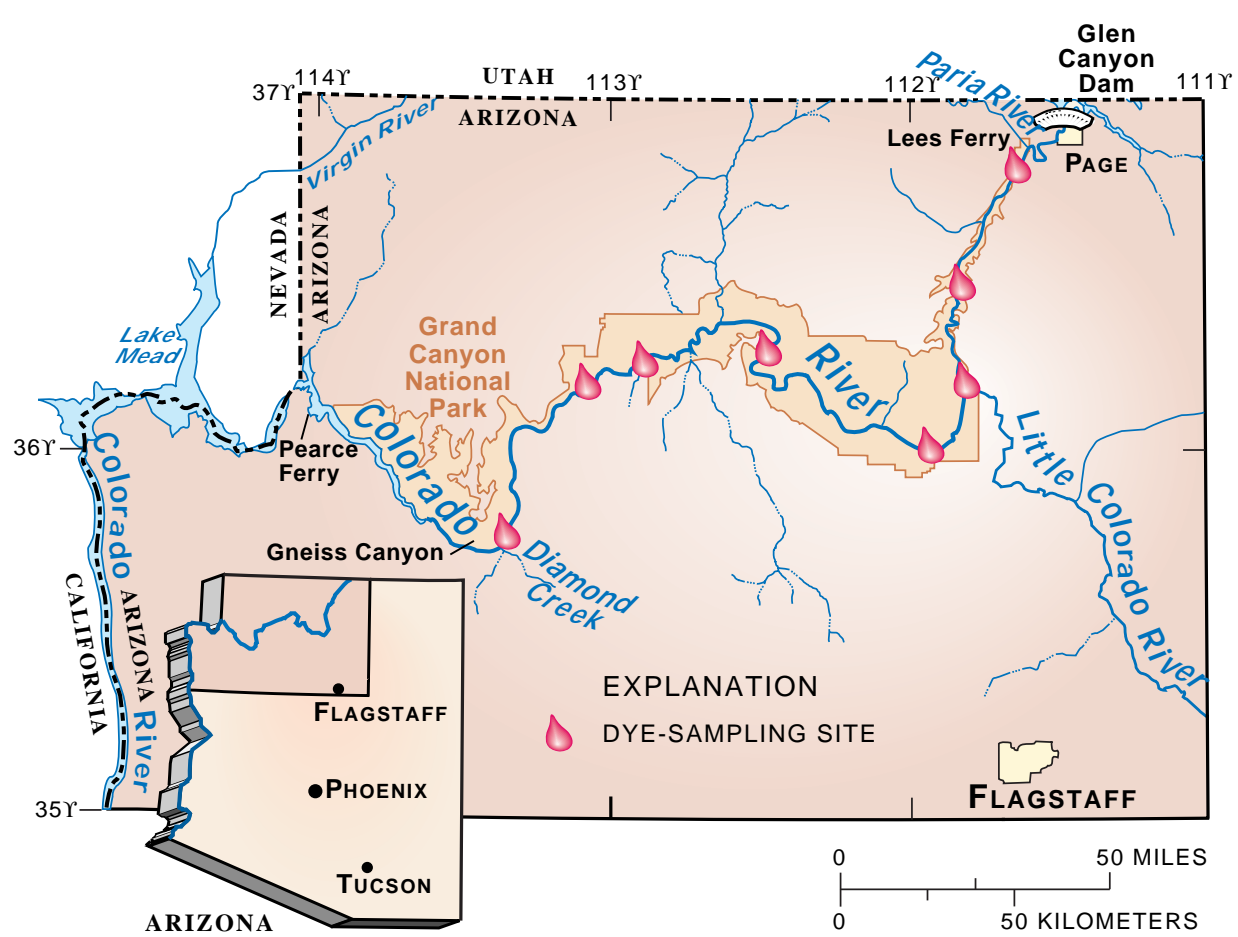

Dye movement was tracked by sampling the water and measuring the dye concentration at eight sites during the controlled flood. 
When Dam Releases are Constant, Water Moves Faster at Higher Dam Releases than at Lower Releases

Measurements of water speed have been made in the Colorado River between Glen Canyon Dam and Lees Ferry at three different dam releases within the operating range of the powerplant at the dam-5,000, 15,000, and $23,000 \mathrm{ft}^{3} / \mathrm{s}$. At the lowest releases, water moved through the reach at an average speed of $0.7 \mathrm{mph}$, taking a little less than 1 day ( 22 hours) to travel the $15 \mathrm{mi}$ between the dam and Lees Ferry. At the highest releases, water moved at $2.3 \mathrm{mph}$ and took about 7 hours to travel the same distance. The speed of water was found to be directly related to the magnitude of dam releases.

The speed of water downstream from Lees Ferry has been measured at two dam releases - 15,000 ft $3 / \mathrm{s}$ in 1991 and $45,000 \mathrm{ft}^{3} / \mathrm{s}$ during the controlled flood of March 1996. At $15,000 \mathrm{ft}^{3} / \mathrm{s}$, the water moved at an average speed of $2.3 \mathrm{mph}$ and took $4 \frac{1}{1} 2$ days to travel the $235 \mathrm{mi}$ from Lees Ferry to Gneiss Canyon, which is $10 \mathrm{mi}$ downstream from Diamond Creek. At that same dam release, water flowed at an average speed of only 1.6 mph from the dam to Lees Ferry. Downstream from Lees Ferry, water traveled almost twice as fast $(4 \mathrm{mph})$ at $45,000 \mathrm{ft}^{3} / \mathrm{s}$ as it had at $15,000 \mathrm{ft}^{3} / \mathrm{s}$.

\section{Flow is Faster in Some Reaches than Others}

The watermo vesthrough the reaches defined by dye-sampling sites faster or slower than the average speed depending on the channel shape and slope of the particular reach. For measurements made at both 15,000 and $45,000 \mathrm{ft}^{3} / \mathrm{s}$, water moves more slowly than average from Lees Ferry to the Lit t le Colorado River, $61 \mathrm{mi}$ downstream, and about equal to or faster than average from that point downstream. The slowestreach downstream from Lees Ferry was in Lower Marble Canyon, which is just upstream from the Little Colorado River.

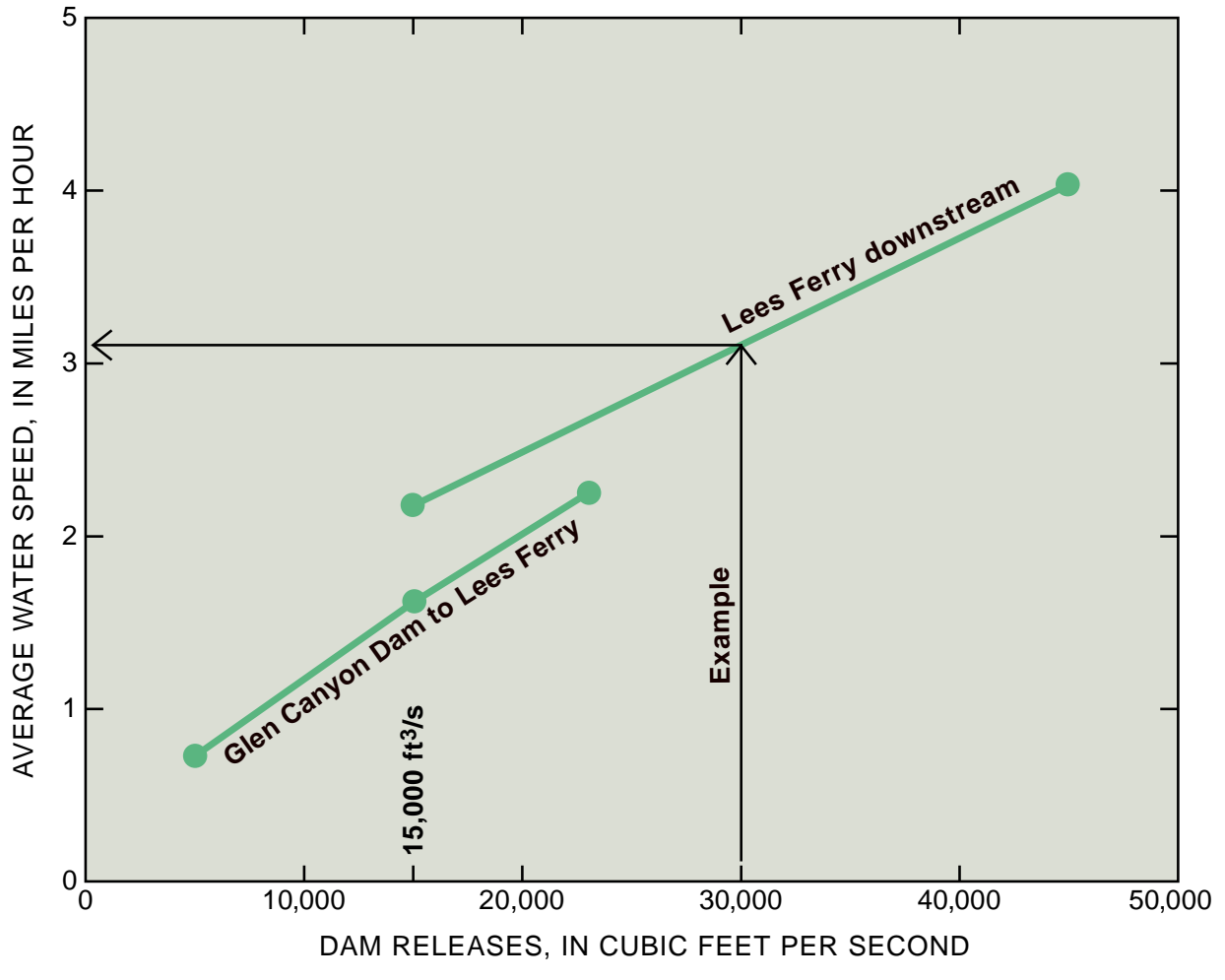

Water speed from the dam to Lees Ferry has been measured at three dam releases and downstream from Lees Ferry at two releases. Wa ter moves a little more slowly upstream from Lees Ferry than downstream. We can use the results to estimate the average water speed for a range of constant discharges. For example, the data indicate that at $30,000 \mathrm{ft} 3 / \mathrm{s}$ water would flow downstream from Lees Ferry at a little more than $3 \mathrm{mph}$.

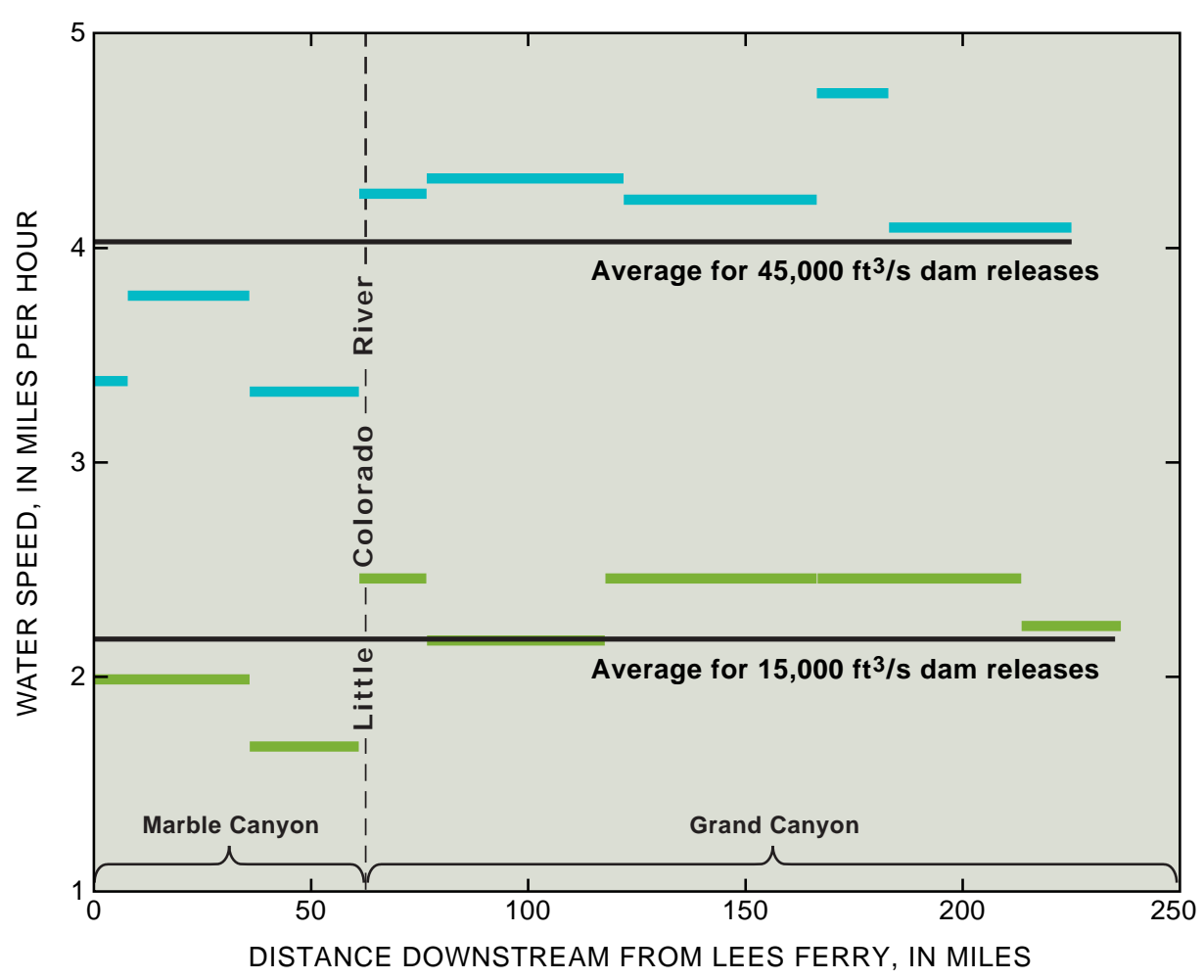

Water speed through reaches defined by sampling sites was less than the average for Marble Canyon and equal to or greater than the average for Grand Ca nyon for both constant dam releases measured. 


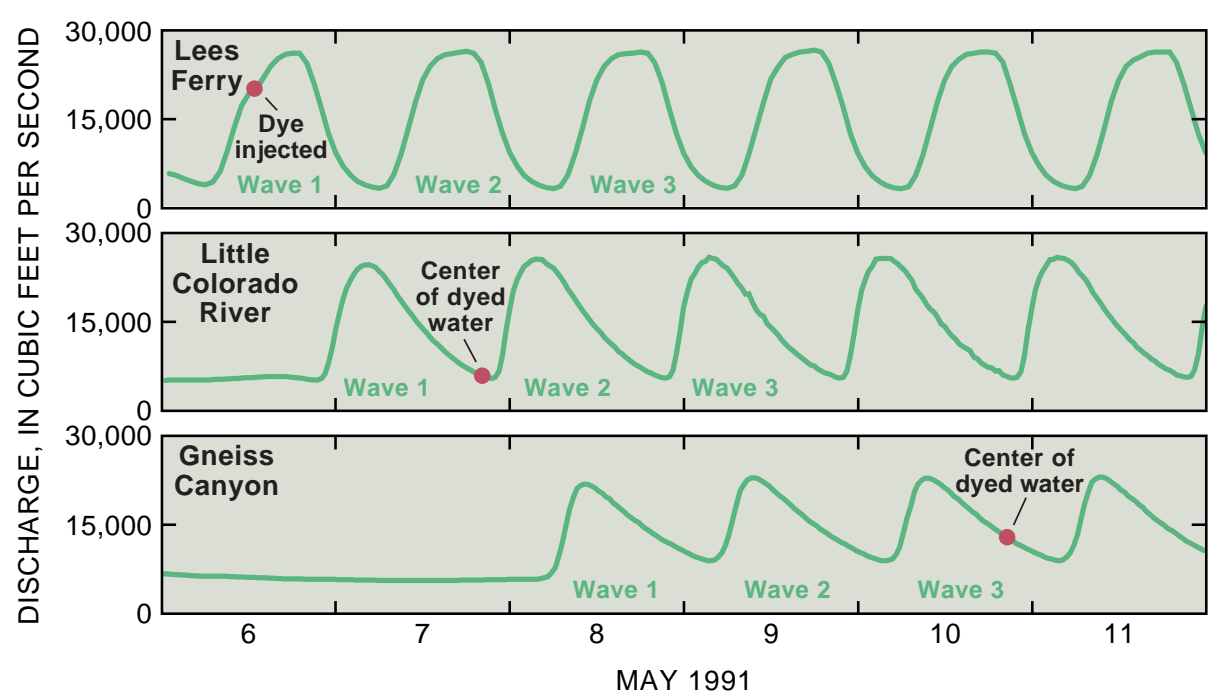

Discharge waves move downstream faster than the water. For example, in May 1991, the discharge waves produced by rapidly changing dam releases moved through the canyon in about $12 / 3$ days, whereas the water took about $4 \frac{1}{3} 3$ days to travel the 235 miles from Lees Ferry to Gneiss Canyon. The dye was injected at Lees Ferry into the discharge wave labeled wave 1 (top graph). Wave 1 passed the Gneiss Canyon sampling location on May 8 , whereas the dyed water passed that location late on May 10.

\section{How do Rapidly Changing Releases Affect the Speed of the Water?}

We've seen that the speed of water released from the dam is higher for higher dam releases when releases are constant throughout the dye measurement. When dam releases change rapidly during the day, as they normally do for production of electricity, a wave of water is produced that moves downstream, but the water itself moves more slowly than the surface wave.

A measurement of water speed was made during an 11-day period in 1991

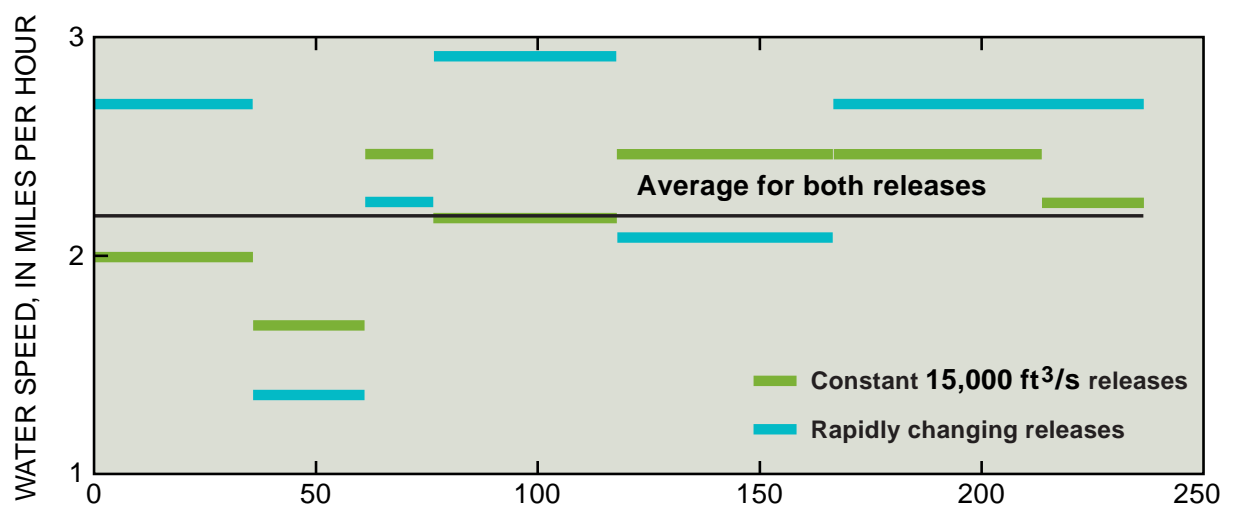

DISTANCE DOWNSTREAM FROM LEES FERRY, IN MILES

Water speed measured in reaches between sampling sites was either higher or lower at rapidly changing releases than at constant releases, depending on whether the dyed water moved through the reach with the peak or trough of the discharge wave.
The difference in speed of the water and the discharge wave caused the water to move through some reaches faster and others more slowly than when releases were constant. The measured water speeds during the rapidly changing releases were higher than those measured during the constant $15,000 \mathrm{f} \mathrm{t}^{3} / \mathrm{s}$ release for the reaches in which the dyed water moved with the higher, faster part of the discharge wave and lower for those in which it moved with the lower, slower part of the wave. Averaged over the whole $235 \mathrm{mi}$ measured, the speed for rapidly changing releases was the same as that measured during the constant $15,000 \mathrm{ft}^{3} / \mathrm{s}$ release.

\section{How has Knowledge of the Water Speed Helped?}

Knowledge of the speed of Colorado River water in Grand Canyon will help managers make decisions needed to protect the unique natural resources. The speed of water through a reach is one factor that controls the amount of time the water is exposed to light. Knowledge of the water speed has helped to provide an understanding of light-dependent processes, such as photosynthesis and respiration of aquatic plants, in the reach between the dam and Lees Ferry. Also, because water speed is controlled in part by channel roughness, which is very difficult to measure directly, measurements of water speed provide a means to determine values of this important channel characteristic. Channel-roughness values computed from the water speed have been used to develop a relation between roughness and river stage that was needed to develop a numerical model that accurately computes discharge throughout the canyon. Accurate knowledge of discharge at any point in the canyon produced by given dam releases is critical to assess ment of effects of those releases on resources.

—Julia B. Graf

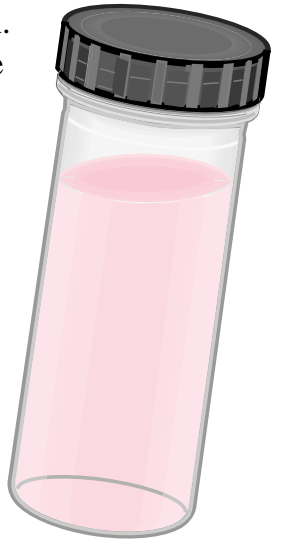




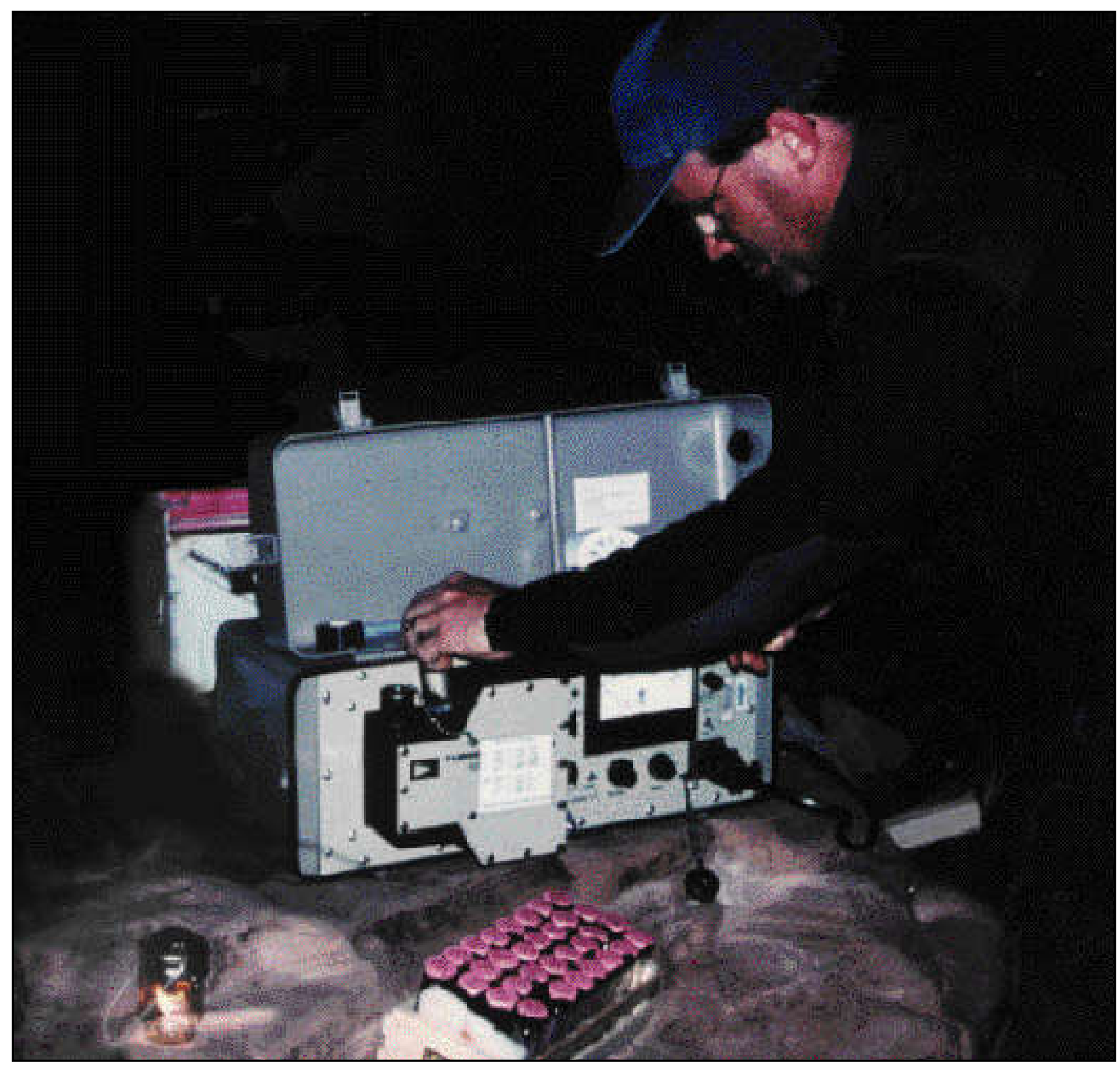

At each site, water samples were collected from near the riv erbank during passage of the dye and measured in the field for dye concentration using a fluorometer. At the site pictured, the dye concentration peaked at around midnight. Samples from all sites were retained and remeasured in the lab under controlled tem perature conditions to obtain the final concentrations.

\section{Selected References}

Graf, J.B., 1995, Measured and predicted velocity and longitudinal dispersion at steady and unsteady flow, Colorado River, Glen Canyon Dam to Lake Mead: Water Resources Bulletin, v. 31 , no. 2 , p. $265-281$.

Konieczki, A.D., Graf, J.B., and Carpenter, M.C., 1997, Streamflow and sediment data collected to determine the effects of a controlled flood in March and April 1996 on the Colorado River between Lees Ferry and Diamond Creek, Arizona: U.S. Geological Survey Open -File Report 97-224, $55 \mathrm{p}$.
Marzolf, G.R., Bowser, C.J., Stephens, D.W., Hart, R.H., and Vernieu, W.S., 1997, Flood effects on benthonic metabolism of carbon and oxygen in Glen Canyon Dam's tailwater: American Geophysical Union, EOS, Transactions, v. 77, no. 46, p. F258.

Wiele, S.M., and Smith, J.D., 1996, A reachaveraged model of diurnal discharge wave propagation down the Colorado River through the Grand Canyon: Water Resources Research, v. 32, no. 5, p. 1375-1386.
For more information contact:

U.S. Geological Survey

520 N. Park Avenue, Suite 221

Tucson, AZ 85719

Julia B. Graf

(520) 670-6671, ext. 252

http://wwwdaztcn.wr.usgs.gov 